\title{
Analysis of cold formed steel sheet pile for earth retaining wall.
}

\section{Análisis de tablestacas de acero conformadas en frío para muro de contención de tierra}

\author{
Veena C, Saravanan S, Robin Davis P, C.G. Nandakumar \\ Department of Civil Engineering, National Institute of Technology Calicut, Calicut, Kerala, \\ India. \\ Corresponding mail id: veenaclakshman@gmail.com
}

\begin{abstract}
Failure loads of sheet pile having various profiles such as $U, Z$ and Omega/Hat profiles under compression was carried out by using equations of strength of materials and compared the failure load under various modes such as Euler's buckling, torsional buckling and failure load due to yielding. Compared the strength of various profiles under flexure by using finite element analysis. Sheet pile can be analyzed as a unit cell for the simplified finite element analysis. For selecting the unit cell sheet pile with omega/Hat section was analyzed for profile containing one to eight numbers and checked the convergence of bending stress and maximum lateral deflection. Interlocks were analyzed for three different conditions such as plane interlock, interlock filled with bitumen and welded interlock. Location of interlock and neutral axis of the wall will affect the stability of the structure. Sheet piles with various cross sections were analyzed and studied the shear stress and bending stress along the cross section. From the structural performance of various cross sections omega/hat section can be considered as the most efficient cross section for the cold formed steel sheet pile because of its more load carrying capacity under compression and high torsion resistance and less bending stress. Results from the finite element analysis for the selection of unit cell shows that the stress and deflection value was converge at the sheet pile having 6 numbers of profiles.
\end{abstract}

\section{RESUMEN}

\section{RESUMEN}

Las cargas de rotura de tablestacas que tienen varios perfiles, como los perfiles $U, Z$ y Omega / Hat bajo compresión, se llevaron a cabo mediante el uso de ecuaciones de resistencia de materiales y se comparó la carga de rotura en varios modos como el pandeo de Euler, pandeo torsional y carga de falla debido flexible. Se comparó la resistencia de varios perfiles bajo flexión mediante el análisis de elementos finitos. La tablestaca se puede analizar como una 
Sustainability, Agri, Food and Environmental Research, (ISSN: 0719-3726), 10(X), 2022:

https://doi.org/10.7770/safer-V10N1-art2480

celda unitaria para el análisis simplificado de elementos finitos. Para seleccionar la celda unitaria de tablestacas con sección omega / Hat, se analizó el perfil que contenía de uno a ocho números y se verificó la convergencia de la tensión de flexión y la deflexión lateral máxima. Los enclavamientos se analizaron para tres condiciones diferentes, como el enclavamiento plano, el enclavamiento relleno con betún y el enclavamiento soldado. La ubicación del enclavamiento y el eje neutral de la pared afectará la estabilidad de la estructura. Se analizaron tablestacas con varias secciones transversales y se estudiaron el esfuerzo cortante y el esfuerzo de flexión a lo largo de la sección transversal. A partir del rendimiento estructural de varias secciones transversales, la sección omega / hat puede considerarse como la sección transversal más eficiente para la tablestaca de acero conformada en frío debido a su mayor capacidad de carga bajo compresión y alta resistencia a la torsión y menor esfuerzo de flexión. Los resultados del análisis de elementos finitos para la selección de la celda unitaria muestran que el valor de tensión y deflexión convergía en la tablestaca que tenía 6 números de perfiles.

\section{INTRODUCTION}

Sheet piles are the structural units which are connected together via interlocking edges to form a wall which can retain solid or liquid. It has number of applications such as retaining walls, river bank protection, cofferdams etc. Fig.1 shows various applications of steel sheet pile. Based on the materials it can be of steel, concrete, wood, etc. But due to more strength and quality control, steel sheet piles are generally preferred. Steel sheet piles can be hot rolled steel sheet piles and cold formed steel sheet piles based on the type of steel used. Fig. 2 shows various applications of steel sheet piles. Cold formed steel sections are generally thin sections as compared to hot rolled steel sections. Moreover, cold formed steel sections are preferred over hot rolled steel sections because of their high strength to weight ratio, easy prefabrication, mass production, fast and easy installation and economy.

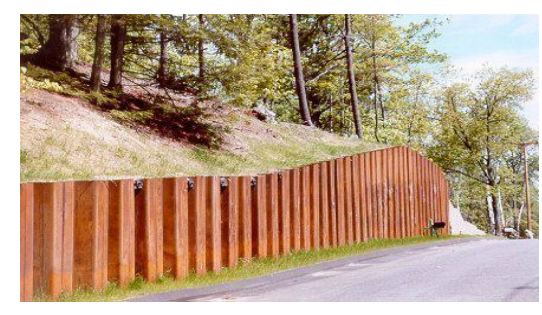

a) Earth retaining wall

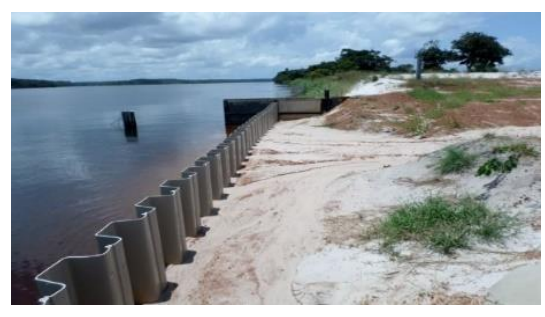

b) River bank protection 
Sustainability, Agri, Food and Environmental Research, (ISSN: 0719-3726), 10(X), 2022:

https://doi.org/10.7770/safer-V10N1-art2480

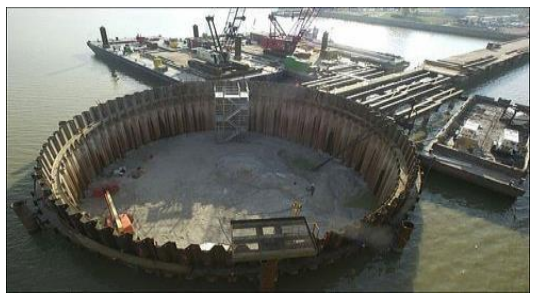

c) Coffer Dam

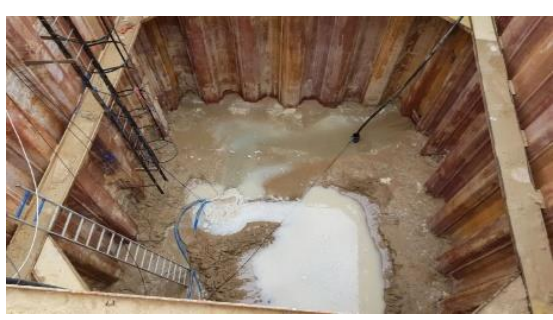

d) Protection for construction pit

Fig.1 Variourious applications of steel sheet pile 


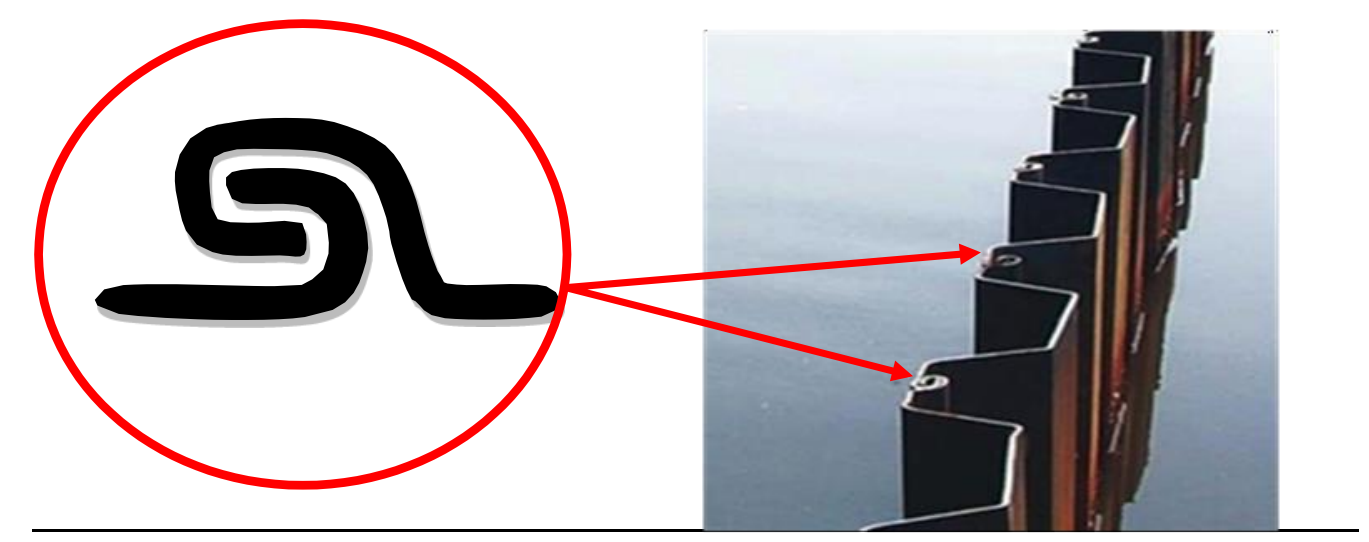

Fig.2 Various applications of steel sheet pile

\section{Design Parameters}

The loads governing the design of a sheet pile wall include applied forces from soil, water, and surface surcharges and the impact from external objects. Horizontal forces applied by soils include, active pressures and passive pressures. Water forces include hydrostatic pressures, which can occur due to differential water levels on either side of the wall. Surcharges include uniform or variable, strip or line and point loads, which rest on the soil surface in the vicinity of the wall and can increase the lateral pressures on the wall.

\section{STRUCTURAL PERFORMANCE OF VARIOUS PROFILES OF STEEL SHEET PILE}

\section{Comparison Of Various Profiles}

There are 3 types of sheet pile profiles which are mainly used for the purpose of retaining wall, Z, U and Omega/Hat profiles. Dimension of the sections used for the comparison study is shown in fig 3 . The thickness of the profile considered as 6,7 and $8 \mathrm{~mm}$ respectively for $Z$, $U$ and omega/hat section. For the purpose of numerical studies each of the profiles are selected in such a way that they have same cross sectional area, span (Profiles of same weight) and fixed at one end. 


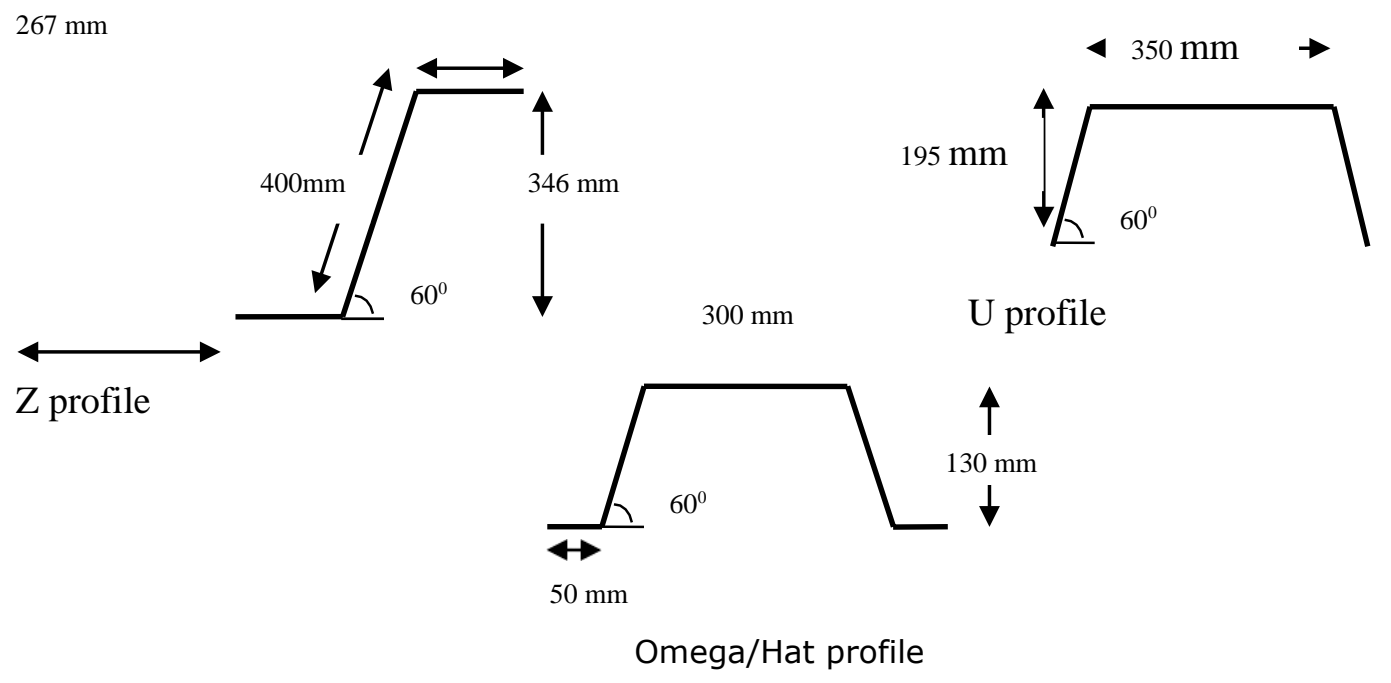

Fig.3 Various shapes of steel sheet pile

From the following Table 1 for a given weight the moment of inertia of the $Z$ section is 1.601 $\mathrm{x} 108 \mathrm{~mm}^{4}$ which is slightly higher than the moment of inertia of the other two sections. Omega section gives the less value of moment of inertia of $9.6 \times 107 \mathrm{~mm} 4$. Torsion constant for omega section obtained as $119466.66 \mathrm{~mm} 4$ which is higher than the other two sections and $Z$ section shows less value of torsion constant of $67248 \mathrm{~mm} 4$. It shows the torsional response of the profile.

Table 1 Comparison of various profiles based on properties

\begin{tabular}{|c|c|c|c|}
\hline Profile & Z profile & U profile & Omega profile \\
\hline $\begin{array}{l}\text { Functional } \\
\text { advantages }\end{array}$ & $\begin{array}{l}\text { Interlocking joints are } \\
\text { away from the centre } \\
\text { line of the wall which } \\
\text { gives protection for the } \\
\text { interlocks }\end{array}$ & $\begin{array}{l}\text { ared to } Z \text { section it has } \\
\text { large width }\end{array}$ & $\begin{array}{l}\text { Large width reduces } \\
\text { the number of piles } \\
\text { and installation time }\end{array}$ \\
\hline Applications & $\begin{array}{l}\text { t can be used for } \\
\text { intermediate to deep } \\
\text { wall construction. }\end{array}$ & $\begin{array}{l}\text { Temporary works such as } \\
\text { retaining walls for } \\
\text { excavation pits }\end{array}$ & $\begin{array}{l}\text { ed for shallower wall } \\
\text { construction }\end{array}$ \\
\hline $\begin{array}{l}\text { Cross- } \\
\text { sectional area } \\
\left(\mathrm{mm}^{2}\right) \text { for a } \\
\text { weight of }\end{array}$ & 5600 & 5600 & 5600 \\
\hline $\begin{array}{l}270.48 \mathrm{Kg} \text { and } \\
\text { Length of } 6 \mathrm{~m}\end{array}$ & & & \\
\hline
\end{tabular}


Sustainability, Agri, Food and Environmental Research, (ISSN: 0719-3726), 10(X), 2022: https://doi.org/10.7770/safer-V10N1-art2480

\begin{tabular}{llrl}
\hline $\begin{array}{c}\text { Moment of } \\
\text { inertia }\left(\mathrm{mm}^{4}\right)\end{array}$ & $1.601 \times 10^{8}$ & $1.215 \times 10^{8}$ & $9.6 \times 10^{7}$ \\
\hline $\begin{array}{c}\text { ional constant J } \\
\left(\mathrm{mm}^{4}\right)\end{array}$ & 67248 & 91466.66 & 119466.66 \\
\hline
\end{tabular}


Sustainability, Agri, Food and Environmental Research, (ISSN: 0719-3726), 10(X), 2022:

https://doi.org/10.7770/safer-V10N1-art2480

Selected profile for the embedded sheet pile

Design of cantilever sheet pile wall can be done by as per IS 9527 part-(III) clause 8.1.1. As per the code pile section can be designed for the maximum bending moment caused by various forces. By using this bending moment suitable section for the sheet pile can be selected by calculating modulus of section of the profile. Omega section of $9.5 \mathrm{~mm}$ thickness has been selected. Cross section of the selected section is shown in fig. 4 its properties are tabulated in table

A

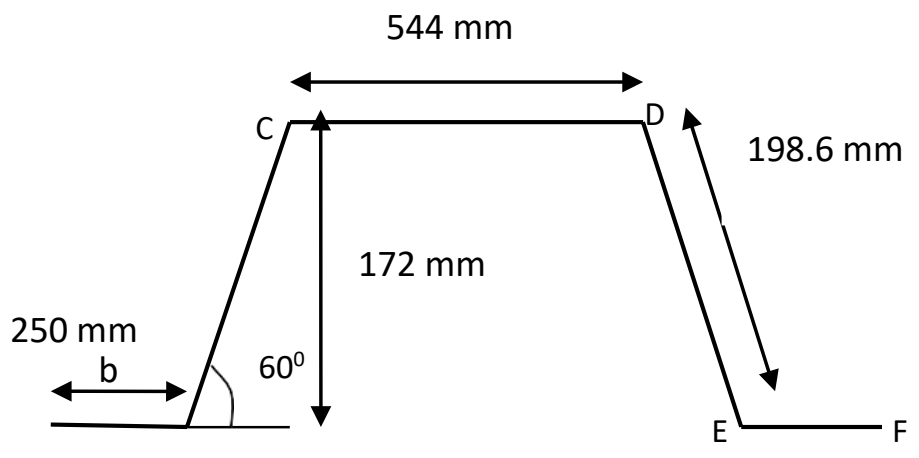

Fig.4 Selected profile for the embedded sheet pile

Table 2 Properties of selected section

\begin{tabular}{lc}
\hline & $\begin{array}{c}\text { Properties of the } \\
\text { selected section }\end{array}$ \\
\hline Thickness & $9.5 \mathrm{~mm}$ \\
Cross section area & $13691.4 \mathrm{~mm}^{2}$ \\
Weight & $172 \mathrm{~kg} / \mathrm{m}$ \\
Moment of inertia & $48336 \times 10^{4} \mathrm{~mm}^{4}$ \\
\hline Section modulus & $2050 \times 10^{6} \mathrm{~mm}^{3}$ \\
\hline
\end{tabular}

\section{RESULTS AND DISCUSSIONS}

Finite Element Analysis of Embedded Sheet Pile Cantilever Retaining Wall

Finite element analysis of the retaining wall shown in fig.5. Analysis is carried out by considering the unit cell containing 6 numbers of profiles and considered the aspect ratio is 3 . Longitudinal bending stress and deflection of the wall was obtained. Fig. 6 shows the loading, deflection and longitudinal stress diagram. Table 3 gives the maximum bending stress and deflection values. Maximum bending stress of $369.7 \mathrm{MPa}$ is occurring at the support. Maximum deflection is at top of the wall which is $134.6 \mathrm{~mm}$. 
Sustainability, Agri, Food and Environmental Research, (ISSN: 0719-3726), 10(X), 2022:

https://doi.org/10.7770/safer-V10N1-art2480

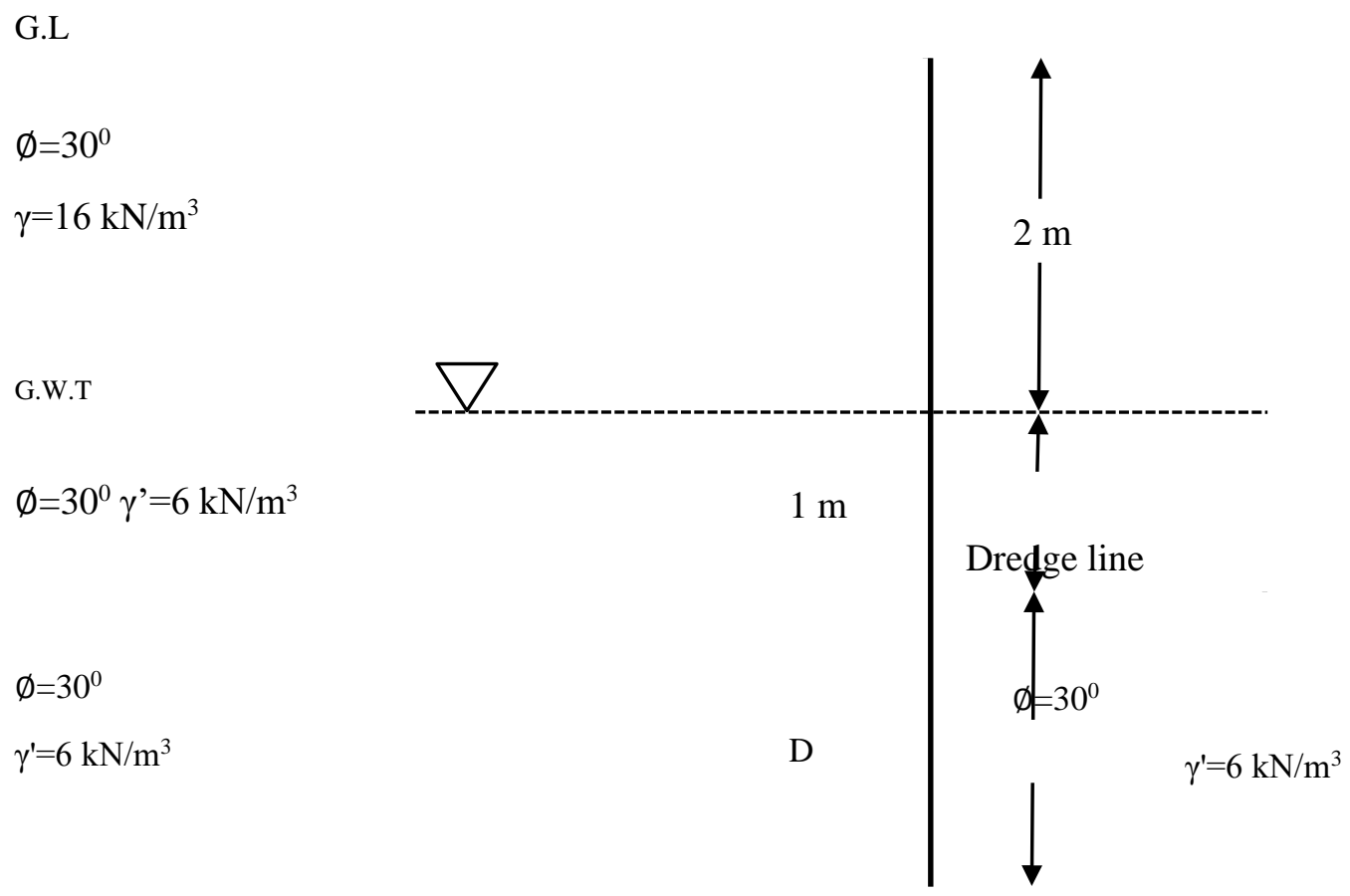

Fig.7 Sheet pile embedded in sandy soil 
Sustainability, Agri, Food and Environmental Research, (ISSN: 0719-3726), 10(X), 2022: https://doi.org/10.7770/safer-V10N1-art2480

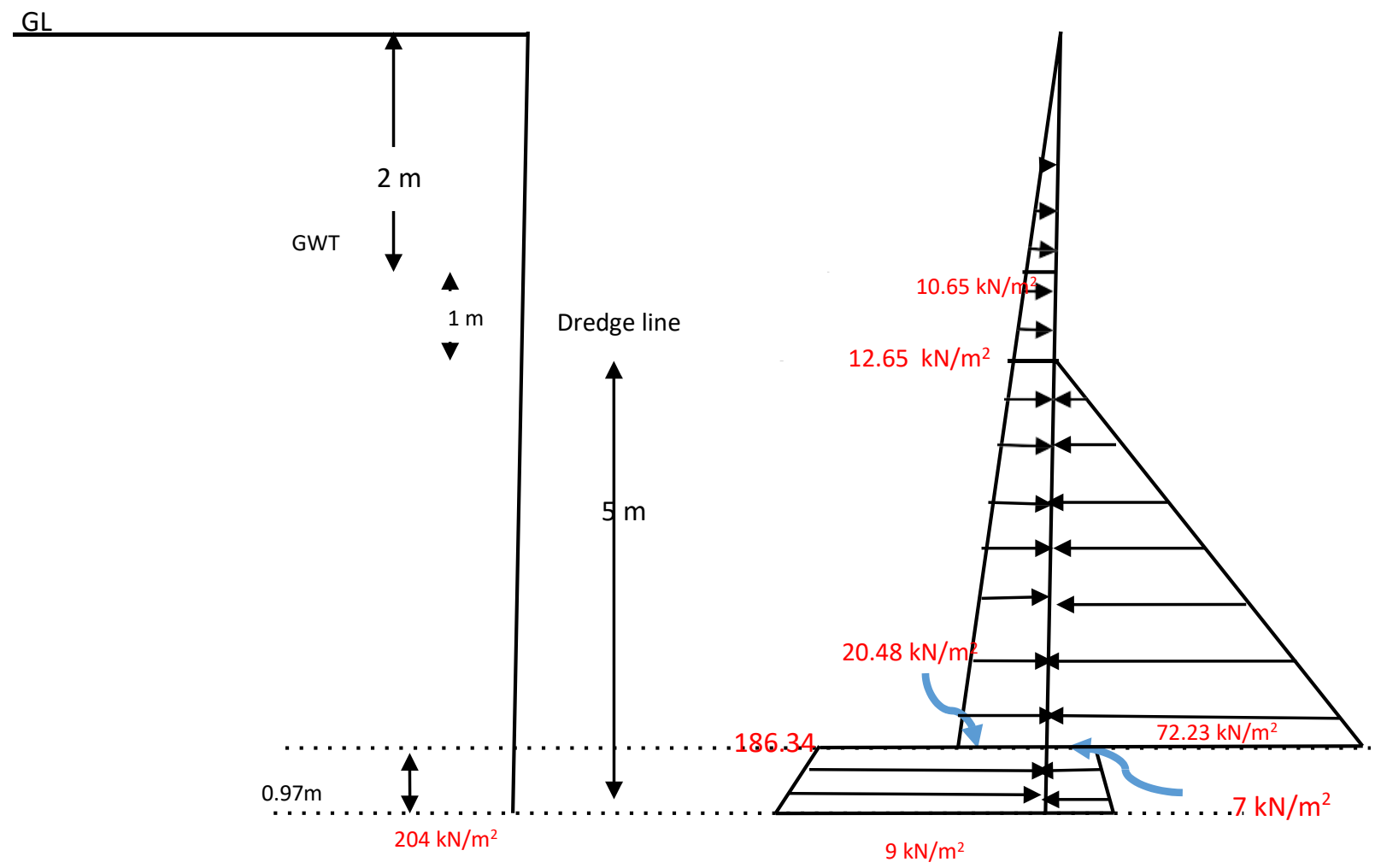

(a)

369.7 MPa

(Maximum stress)

(b)
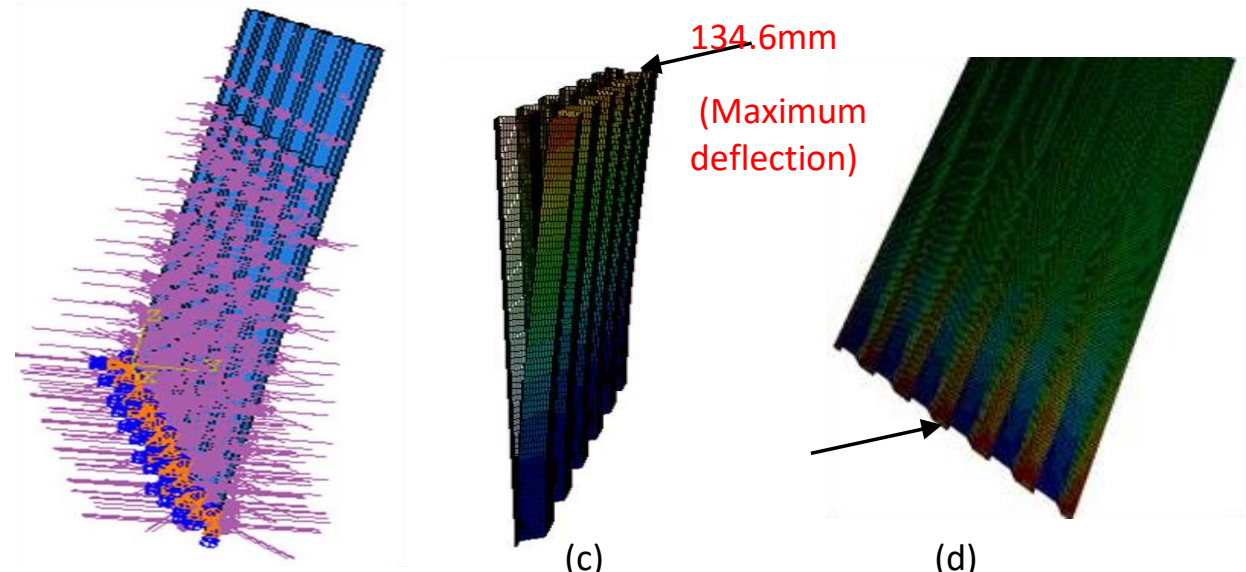

(c)

(d)

Fig 6 Unit cell for the sheet pile analysis

(a) Schematic loading diagram (b) loading diagram in finite element

(c) Deflection diagram (d) longitudinal stress diagram 
Sustainability, Agri, Food and Environmental Research, (ISSN: 0719-3726), 10(X), 2022:

https://doi.org/10.7770/safer-V10N1-art2480

Table 3 Maximum longitudinal stress and Maximum displacement from the finite element analysis of embedded sheet pile

\begin{tabular}{cc}
\hline Maximum longitudinal stress & $369.7 \mathrm{MPa}$ (at support) \\
\hline Maximum displacement & $134.6 \mathrm{~mm}$ (at top) \\
\hline
\end{tabular}

Finite Element Analysis of Sheet Pile Joints

Sheet pile having length of $1 \mathrm{~m}$, thickness of $6 \mathrm{~mm}$ cross-section shown in fig.7 fixed at the bottom, is considered for the finite element analysis of joint. Unit load of $1 \mathrm{~N} / \mathrm{mm} 2$ applied to the joint.

$114.5 \mathrm{~mm}$

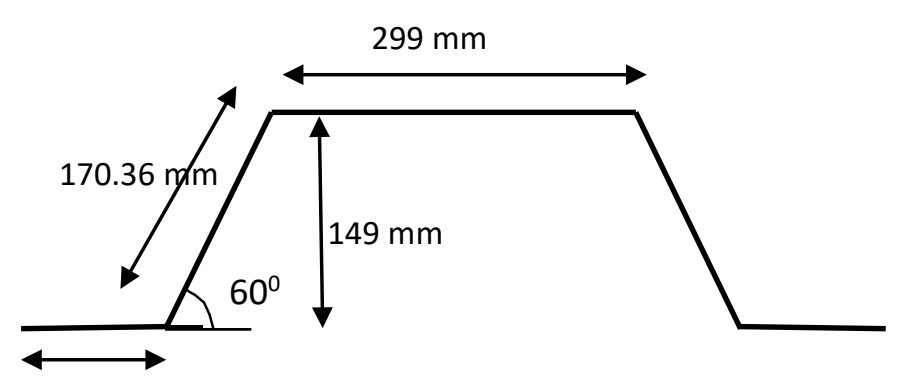

Fig.7 Sheet pile cross section used for analysis of joints

Analysis of Interlock Joints for Various Cross Sections

Interlocks for different cross sections are located on different positions. After interlocking each profile the wall is acting as a single structure. Bending stress will be minimum at the neutral axis of the wall and maximum at the sides. Maximum shear stress will be at the neutral axis and minimum at sides. At the loading condition shear stress is transferred through the interlocks.

\section{Analysis of interlock in ' $U$ ' section}

In ' $U$ ' type profiles interlock is located at center line of the wall. Four nodded thin shell type of linear quadrilateral element of aspect ratio 3 is used for the finite element analysis. Four numbers of profiles are connected. Bending stress values and shear stress values along the cross section is obtained from the analysis is shown in Table 4

Fig. 8 shows the depth of cross section v/s bending stress and Fig. 9 shows depth of cross section $\mathrm{v} / \mathrm{s}$ shear stress. From the graph it shows that bending stress gives zero at the height of $195 \mathrm{~mm}$ and where shear stress shows maximum value of $3.58 \mathrm{MPa}$. Shear stress is 
Sustainability, Agri, Food and Environmental Research, (ISSN: 0719-3726), 10(X), 2022:

https://doi.org/10.7770/safer-V10N1-art2480

minimum at the ends of the section with value of $0.13 \mathrm{MPa}$ and $0.1 \mathrm{MPa}$. Shear stress is transferred through the interlock during loading condition and it is maximum at the neutral axis. Interlocks are the weakest point in the sheet pile wall it will affects by more shear stress, it leads to the inter pile slippage and finally leads to the failure of the wall.

Table 4 Bending stress and shear stress values along the cross section for $U$ profile sheet pile

\begin{tabular}{lll}
\hline $\begin{array}{l}\text { Height of cross section } \\
(\mathrm{mm})\end{array}$ & Bending stress (MPa) & Shear stress (MPa) \\
\hline 0 & -12.05 & 0.13 \\
39 & -3.47 & 2.23 \\
78 & -2.66 & 2.66 \\
117 & -1.85 & 3.03 \\
156 & -1.01 & 3.317 \\
195 & 0 & 3.58 \\
234 & 0.52 & 3.54 \\
273 & 1.42 & 3.39 \\
312 & 2.28 & 3.16 \\
351 & 3.13 & 2.84 \\
\hline 390 & 12.01 & 0.1 \\
\hline
\end{tabular}

450

400

350

300

250

200

150

100

50

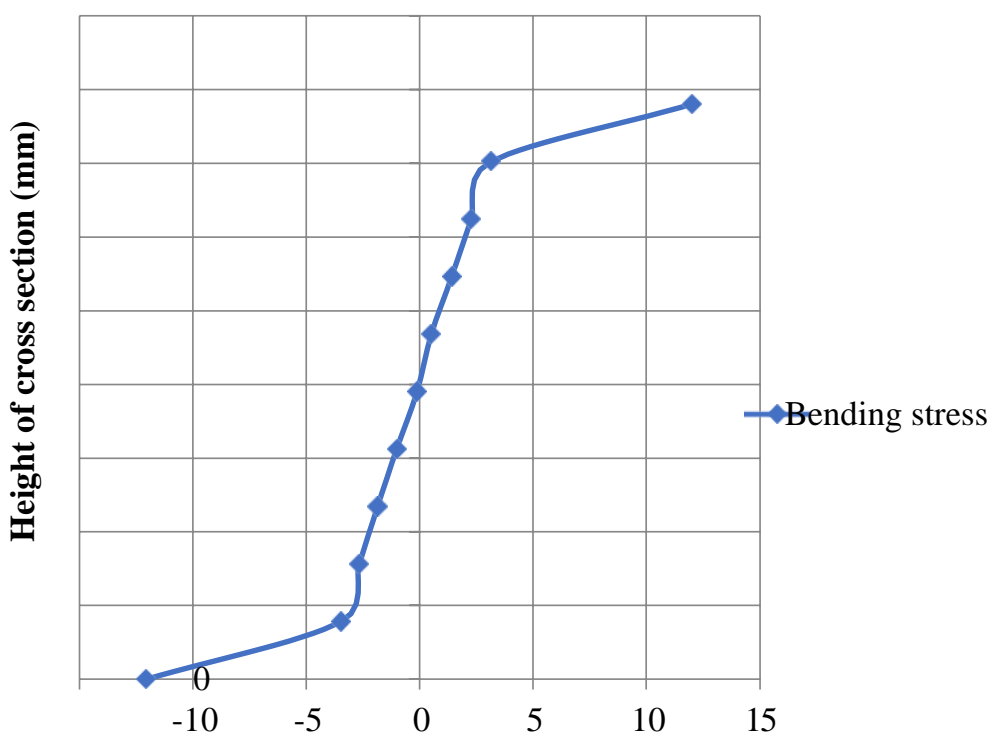

Bending stress (MPa)

Fig. 8 Height of cross section $v / s$ bending stress for $U$ profile sheet pile 
Sustainability, Agri, Food and Environmental Research, (ISSN: 0719-3726), 10(X), 2022:

https://doi.org/10.7770/safer-V10N1-art2480

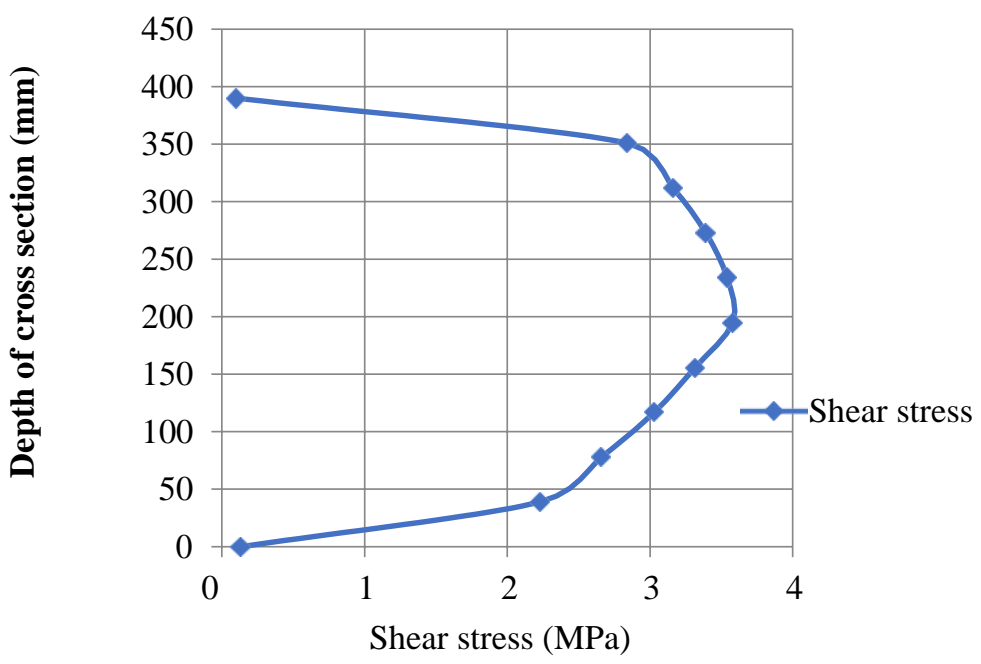

Fig. 9 Height of cross section $v / s$ shear stress for $U$ profile sheet pile

\section{Analysis of interlock in ' $Z$ ' section}

In $Z$ section sheet piles the number of interlocks per unit length is more compare to the other profiles and it is located at the outer end of the section at both sides of centerline of the wall. Four nodded thin shell type of linear quadrilateral element of aspect ratio 3 is used for the finite element analysis. Four profiles are connected. Shear stress and bending stress values obtained by the analysis is tabulated in the table 5. Fig. 10 shows the depth of cross section $\mathrm{v} / \mathrm{s}$ bending stress and fig. 11 shows depth of cross section $\mathrm{v} / \mathrm{s}$ shear stress. The neutral axis of the wall is located $150 \mathrm{~mm}$ from the bottom of the section. From the table the maximum shear stress and zero bending stress at the cross section height of $150 \mathrm{~mm}$. It shows that maximum shear stress is occurs at the area of neutral axis where bending stress is zero. Fig 11 shows that at the end of the section shear stress is minimum. So that interlock will affected by zero or negligible value of shear stress, it gives the safety to the interlock and stability for the wall. 
Sustainability, Agri, Food and Environmental Research, (ISSN: 0719-3726), 10(X), 2022:

https://doi.org/10.7770/safer-V10N1-art2480

Table 5 Shear stress and bending stress values along the cross section for $Z$ profile sheet pile

\begin{tabular}{ccc}
\hline Height of cross section $(\mathrm{mm})$ & Bending stress (MPa) & Shear stress (MPa) \\
\hline 28.2 & -13.531 & 0.08 \\
56.4 & -6.08 & 3.35 \\
84.6 & -4.8 & 3.8 \\
112.8 & -3.01 & 3.92 \\
150 & -1.412 & 4.13 \\
169.2 & 0.91 & 4.15 \\
197.4 & 1.93 & 4.12 \\
225.6 & 3.53 & 4.033 \\
253.8 & 4.5 & 3.75 \\
282 & 6.522 & 3.56 \\
300 & 13.96 & 3.03 \\
\hline
\end{tabular}

Table 6 Shear stress and bending stress values along the cross section for $Z$ profile sheet pile

\begin{tabular}{ccc}
\hline $\begin{array}{l}\text { Height of cross } \\
\text { section } \\
(\mathrm{mm})\end{array}$ & $\begin{array}{l}\text { Bending stress } \\
(\mathrm{MPa})\end{array}$ & $\begin{array}{l}\text { Shear stress } \\
(\mathrm{MPa})\end{array}$ \\
\hline 10.8 & -13.19 & 0.096 \\
21.6 & -4.26 & 3.78 \\
32.4 & -2.53 & 4.25 \\
43.2 & -1.63 & 4.44 \\
54 & -0.39 & 4.67 \\
64.8 & 0.472 & 4.7 \\
75.6 & 1.78 & 4.67 \\
86.4 & 2.45 & 4.47 \\
97.2 & 4.17 & 4.18 \\
108 & 3.74 & 4.19 \\
\hline 118.8 & 7.08 & 3.85 \\
\hline
\end{tabular}


Sustainability, Agri, Food and Environmental Research, (ISSN: 0719-3726), 10(X), 2022: https://doi.org/10.7770/safer-V10N1-art2480

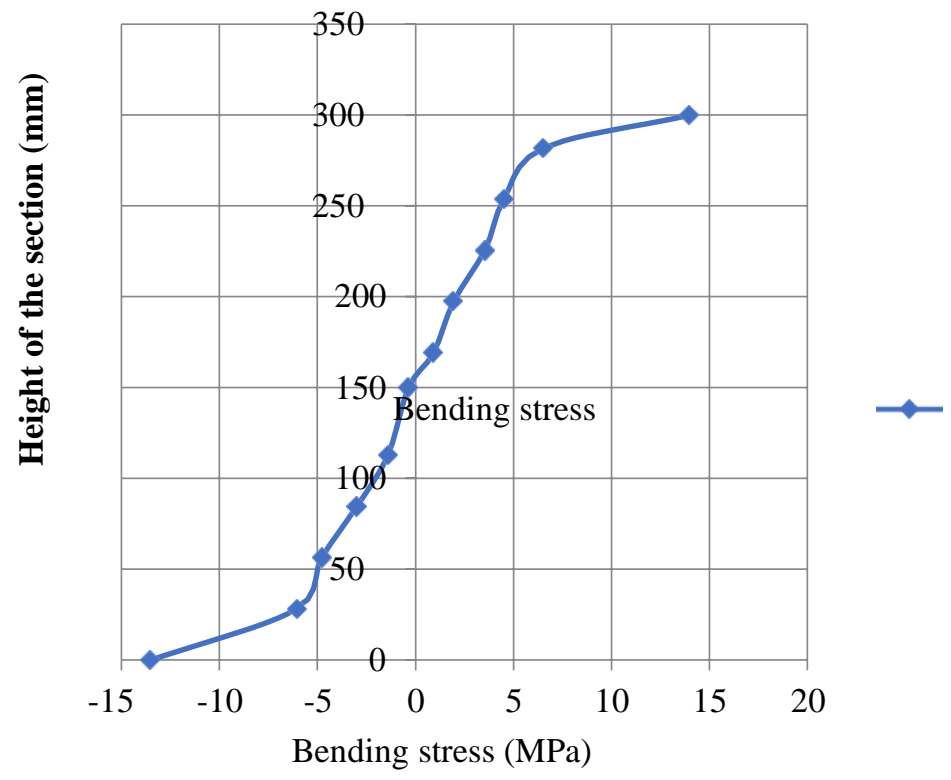

Fig.10 Height of cross section $\mathrm{v} / \mathrm{s}$ bending stress for $Z$ profile sheet pile

350

300

250

200

100

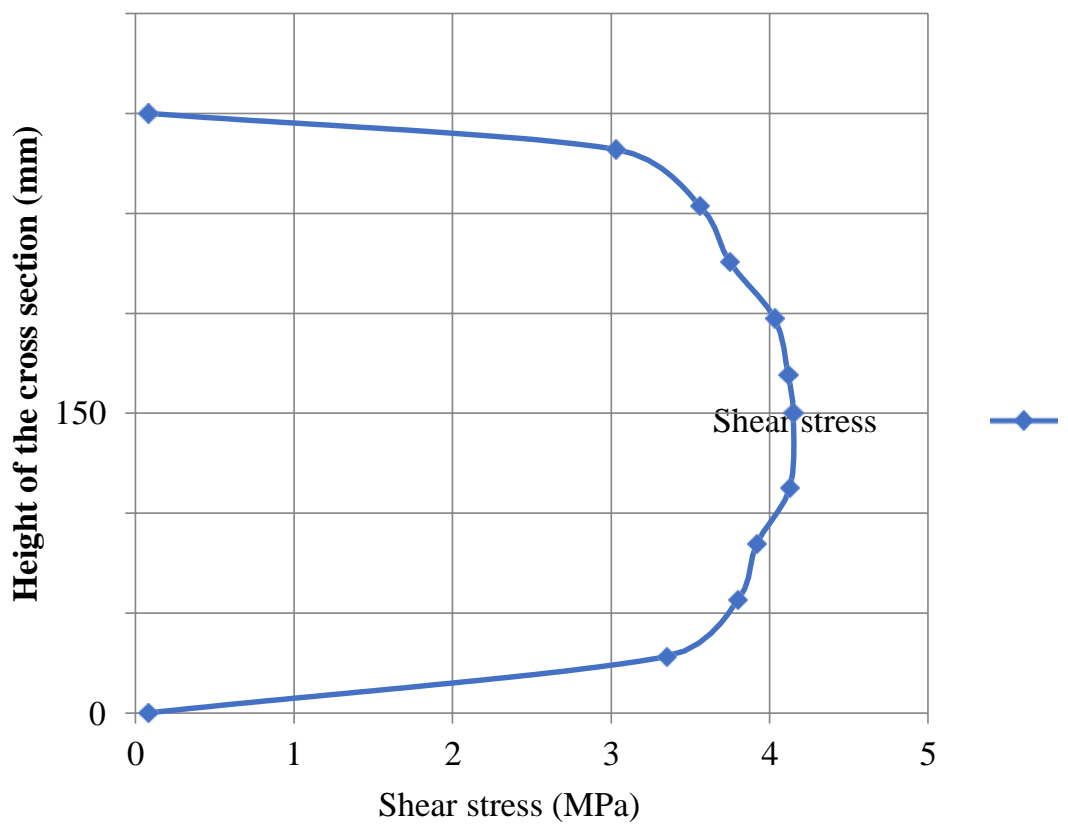

Fig. 11 Height of cross section $\mathrm{v} / \mathrm{s}$ shear stress for $Z$ profile sheet pile

Analysis of interlock in Omega/Hat section

Interlocks arrangement in omega profile is same like $Z$ profile. It located at the outer end of the wall. But it is located only one side of the center line of the wall. The number of sheet pile 
Sustainability, Agri, Food and Environmental Research, (ISSN: 0719-3726), 10(X), 2022:

https://doi.org/10.7770/safer-V10N1-art2480

per unit length is less compare to the other profiles 
Sustainability, Agri, Food and Environmental Research, (ISSN: 0719-3726), 10(X), 2022:

https://doi.org/10.7770/safer-V10N1-art2480

due to its large width. Four nodded thin shell type of linear quadrilateral element of aspect ratio 3 is used for the analysis. From the analysis bending stress and shear stress distribution values along the cross section is obtained and it is tabulated in table 6. Fig 12 shows height of section $\mathrm{v} / \mathrm{s}$ bending stress and fig. 13 shows height of section $\mathrm{v} / \mathrm{s}$ shear stress.

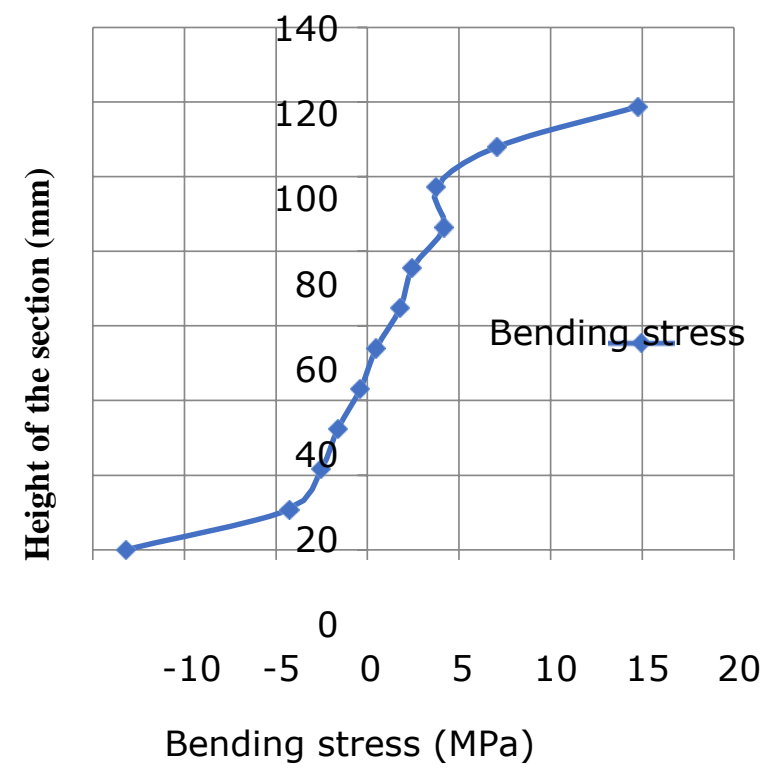

Fig. 12 Height of cross section v/s bending stress for Omega/Hat profile sheet pile 


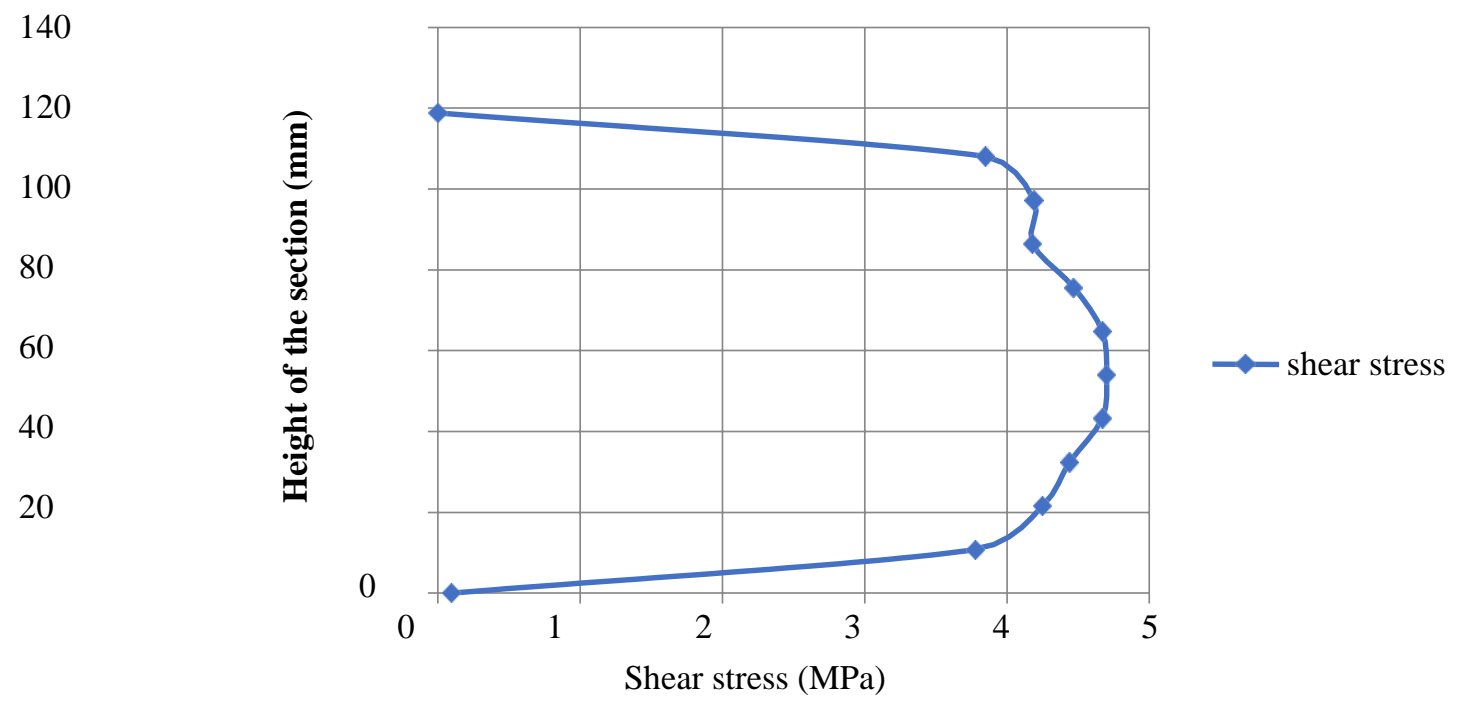

Fig.13 Height of cross section v/s shearing stress for Omega/Hat profile sheet pile

\section{SUMMARY AND CONCLUSIONS}

The salient conclusions of the present study are as follows:

- Different types of steel sections are using such as $U, Z$ and omega/hat sections. Among these sections Omega section is the most effective cross section for cold formed steel retaining wall. It has more torsion resistance, compressive resistance and low bending stress and low deflection.

- Type of loads acting, Depth of penetration and design of sheet pile wall can be done by using IS 9527 part (III).

- $\quad$ Finite element analysis of the sheet pile retaining wall can be done by using a four nodded thin shell type of linear quadrilateral element with aspect ratio 3.

- $\quad$ Finite element analysis of the retaining wall can done by considering the sheet pile as a unit cell containing 6 numbers Omega/ Hat profiles.

- Hook and grip interlock is using for cold formed steel sheet piles. Interlocks are welded or applied by some adhesive material like bitumen to make the interlock leak proof and to prevent interpile slippage. Compared to plane interlock and interlock with weld, Interlock filled with bitumen gives low deflection and low bending stress under loading.

- Interlocks are the weakest points in sheet pile wall. Position of interlock and location of neutral axis will affect the stability of the structure. In loading condition, load is transferred through the interlocks by shear stress. Shear stress will be maximum at the neutral axis of the structure.

- In case of $U$ section position of interlock and neutral axis are same. More stress will act to the interlock. It causes the interlock slippage, it leads to the failure of sheet pile wall. 
Sustainability, Agri, Food and Environmental Research, (ISSN: 0719-3726), 10(X), 2022:

https://doi.org/10.7770/safer-V10N1-art2480

Interlock for $\mathrm{Z}$ and Omega/Hat section is away from the neutral axis of the wall where shear stress is zero or negligible.

\section{REFERENCE}

A.S. Pechstein et.al : A continuous material law for modeling thin-sheet piles and their frictional connection, European Journal of Mechanics A/Solids, Vol.30, No.4, April 2011, pp 684-695

Adegoke and Emmanuel Kelechi -Soil sheet pile interaction: Part 1:A review of theories and design methods, International journal of civil engineering and technology, Volume 6, No.5, May 2015

Anasua GuhaRay and Dilip Kumar Baidya, Reliability: Based Analysis of Cantilever Sheet Pile Walls Backfilled with Different Soil Types Using the Finite-Element Approach, International journal of Geomechanics Vol. 15, No. 6, June 2015

Athanasopoulos, Vlachakis, and. Pelekis: Installation and performance of a steel sheet pile wall for supporting an excavation in urban environment, Geo-Frontiers 2011, Geotechnica 1 Special Publication 211, 3370-3380

Azzam and Elwakil: Performance of axially loaded piled retaining wall: Experimental and numerical analysis. International journal of Geomechanics, Vol. 17, No.2, February 2017.

Babu, and Bash: Optimum design of cantilever sheet pile walls using inverse reliability approach- Journal of Geotechnical engineering, Vol.35, No.2, April 2008, pp 134-143.

Crawford and Byfield: A numerical model for predicting the bending strength of Larssen steel sheet piles, Journal of Constructional Steel Research, Vol.58, No.10, October 2002, pp 1361-1374.

Dina A. Emarah and Safwat A. Seleem : A numerical study of anchored sheet piles subjected to different types of sandy soils backfill, Housing and Building National Research Center, vol.14, No.3, March 2018, pp 424-430

Doubrovsky and Meshcheryakov: Physical modeling of sheet piles behavior to improve their numerical modeling and design, Journal of Soils and Foundations Engineering, Vol. 55, No.4, April 2015, pp 691-702

Fanny Deckner et.al: Wave Patterns in the Ground: Case Studies Related to Vibratory Sheet Pile Driving, Journal of Geotechnical engineering, vol.35, 2017, pp 2863-2878

Felipe Uribe-Henao and Arboleda-Monsalve: Sheet Pile Interlocks and Ring Beam Installation Effects on the Performance of Urban Cofferdams, Geotechnical Frontiers, the University of Newcastle on March 2017.

Gopal Madabhushi and Chandrasekaran- Rotation of Cantilever Sheet Pile Walls-ASCE- 
Sustainability, Agri, Food and Environmental Research, (ISSN: 0719-3726), 10(X), 2022:

https://doi.org/10.7770/safer-V10N1-art2480

Journal of Geotechnical and Geo- environmental Engineering, Vol.131, No. 2, February 2005,pp 202-212

Gregory P. Tsinker: Pile jetting, Journal of geotechnical engineering, Vol.114,1988, pp 326334

H. Schmieg et.al: Transmission of Shear Forces in Sheet Pile Interlocks, Journal of Geotechnical and Geo environmental Engineering, Vol.128, No. 4, April 2002, pp. 292297

Ha Ik Chung et.al: Application of steel sheet pile embedment as a bridge abutment, Journal of Geo transportation Engineering, 2004

J. B. Sellmeijer et .al: Hydraulic resistance of steel sheet pile joints, Journal of Geotechnical engineering, Vol 121, No.2,February 1995, pp 105-110

K. Rainer Massarsch and Bengt H. Fellenius: Ground Vibrations Induced by Impact Pile Driving, International Conference on Case Histories in Geotechnical Engineering, Missouri University of Science and Technology, Aug 11th - Aug 16th,2008

Kouichi et.al : Static analysis model for double sheet pile wall structures, Journal of Geotechnical Engineering, Vol. 114, No.7, July 1988, pp 510-825.

Matthew Stuart: Project-specific steel sheet piling applications, Practice periodical on structural design and construction, vol. 9 ,no 4, April 2004, pp 194-201.

Mawer and Byfield,- Reduced Modulus Action in U-Section Steel Sheet Pile Retaining WallsJournal of Geotechnical and GeoEnvironmental Engineering, Vol. 136, No.3 , March 2010, pp 439-444

Omer Bilgin- Lateral Earth Pressure Coefficients for Anchored Sheet Pile Walls, International journal of Geomechanics, Vol.12, No.5,May 2012, pp 584-595

P. Billet and J. G. Sieffert: Soil-sheet pile interaction in vibro-piling, Journal of Geotechnical engineering, Vol. 115, 1989, pp 1085-1101.

Rens Liu, and Foltz: Sustainable approach for optimal steel sheet pile structure assessment, maintenance, and rehabilitation, Journal of performance of constructed facilities, Vol. 27, No. 2, February 2013, pp 181-190

Robert and Fellow: Analysis of cantilever sheet pile walls in cohesionless soil, Journal of Geotechnical and Geo environmental Engineering, Vol.123, No.1, January 1997, pp 8284.

Rowe-A Theoretical and Experimental Analysis of Sheet-Pile Walls-Proceedings of the Institute of Civil Engineering, Jan., 1955, pp. 32-8

Takefumi.et.al: Development of Very Low Head Room Press-In Sheet pile Driver, International Foundations conference and Equioment Expo, March 2015, pp 17-21 
Sustainability, Agri, Food and Environmental Research, (ISSN: 0719-3726), 10(X), 2022:

https://doi.org/10.7770/safer-V10N1-art2480

Williams and Little: Structural behaviour of steel piles interlocked at the centre of gravity of the combined section, Proceeding instituition of civil engineering Structures and buildings, Vol.94, No. 2, February 1992, pp 229-238.

Received: $30^{\text {th }}$ January 2021; Accepted: $14^{\text {th }}$ March 2021; First distribution: 01th April 2021 